\title{
Tourism Potential in Nagari Kamang Hilia, Agam Regency West Sumatera
}

\author{
Rini Eka Sari ${ }^{1}$, Novi Yanita ${ }^{2}$, Abdiani Khairat Nadra ${ }^{3}$ \\ rini@pnp.ac.id, noviyanita@pnp.ac.id, abdiani@pnp.ac.id
}

Business Administration Department, Politeknik Negeri Padang ${ }^{123}$

\begin{abstract}
This paper explores the tourism potential in Nagari Kamang Hilia, Agam Regency, West Sumatera Province, Indonesia, analyzed from the concept of tourism attraction. As an area granted with the natural beauty, Nagari Kamang Hilia has hills, caves, and forests. Besides, it also has farming land for rice field, cocoa, dragon fruit, orange, durian and cassava. The study used qualitative approach. Data collection is obtained by conducting observation, in depth interview to several related informants and also documentation study. The data is then analyzed by using triangulation, comparing the result of observation, in depth interview and documentation study. The research finding reveals that there are some villages in Nagari Kamang Hilia that have tourism potentials in the form of natural attractions, cultural and artificial attractions to be developed as soft adventure tourism, rural tourism, and cultural and history tourism.
\end{abstract}

Keywords : Tourism Potential, Tourist Attraction, Nagari Kamang Hilia

\section{Introduction}

Tourism sector has been considered as one of economic driven since it can give multiplier effects to the community. Over the past six decades, tourism has experienced continued expansion and diversification to become one of the largest and fastest-growing economic sectors in the world. According to United Nation World Tourism Organization (UNWTO), tourism comprises the activities of persons traveling to and staying in places outside their usual environment for not more than one consecutive year for leisure, business and other purposes [1]. In Indonesia, tourism is also considered as priority sector that generates income to the country. In 2016, tourism sector was in the $4^{\text {th }}$ ranking of Indonesian income contributor. Indonesian Law number 10, 2009 defined tourism as various tourism activities, supported facilities and services provided by society, entrepreneurs, government, and regional governments [2].

In many places in Indonesia, new tourism destinations are created to increase the number of tourist visit. To do such a thing, it is possibly conducted by identifying the tourism potential in one area. One of the areas in West Sumatera, Indonesia which is now developing tourism as a leading sector is Agam Regency. It consists of 16 Districts and 82 Nagari. According to Regional Law of Agam Regency, Nagari is a unity of community's customary law in West Sumatera Province consisting of a set of clans that have a certain bordered territory, assets, and have rights to regulate and organize its own area and select the leader of its government [5]. The uniqueness of Agam Regency is that this region has all in one region natural attractions from beach, lake, hills, river, forest, to mountains. Having the natural potential, Agam Regency is now trying to create new tourism destination through empowering the Nagari. Nagari Kamang Hilia, is one of the areas in Agam regency that has various tourism potential. This study aimed to identify the tourism potentials in Nagari Kamang Hilia which is analyzed using the concept of tourist attraction. It will discuss the components of tourist attractions Nagari Kamang Hilia have and also to classify them into the tourism development that possibly suggested to Nagari Kamang Hilia. It is necessary to identify the tourism potential of a tourist destination to create a uniqueness that cannot be found in other area.

Tourism potential is the ability in an area that can be used as the development includes nature and people and the work of human beings themselves [3]. It also can be defined as everything that exists in a tourist destination and it attracts people to visit the site [4]. Tourism potential is all resources owned by a tourism attractions and it is useful to develop the tourism 
industry in that area [2]. It can be tangible or intangible things which is provided and arranged as the capability, factors and elements needed or determined to the development of tourism in the form of atmosphere, event, things or service [2]. In general, it can be concluded that tourism potential is all resources which can attracts people to visit, in the form of tangible and intangible things such as nature, people and artificial things that will be useful to develop a tourism destination. Tourism potential can be classified into three types:

a. Natural resources attractions; an attraction developed mainly based on natural beauty and the uniqueness provided by nature such as beach with its magnificent tides, forest and savanna with their authentic flora and fauna, the river with its crystal clear water and awesome stream, waterfall with the spectacular steepness and so many others.

b. Cultural attractions; an attraction developed mainly based on human creations and masterpieces, be it cultural heritage or sites as well as living cultural values in the form of ceremonies, rituals, customs, performing arts, sculptures, fine arts, literatures as well as the uniqueness of the way they living.

c. Artificial attractions; an attraction developed mainly based on activities to fulfill tourist wants and needs specifically such as rides and other facilities in amusement park, entertainment, sports event and many others.

Tourism potential later possibly becomes the embryo to develop a tourist attraction. A tourist attraction is a permanent resource which derives all or part of its income from visitors and which is managed for the primary purpose of leisure and visitor enjoyment [5]. Tourist attractions are often the reason for visiting a particular destination as they provide activities and experiences at the destination and a means of collecting the signs of tourism consumption . Tourism resources, products, and services offered by a destination are the most important aspects defining the attraction for a tourist [3]. Attractions are often the focus of visitor attention and may provide the initial motivation for the tourist to visit the destination. These can be categorized as natural (e.g. beaches, mountains, parks, weather), built (e.g. iconic buildings such as the Eiffel tower, heritage monuments, religious buildings, conference and sports facilities), or cultural (e.g. museums, theatres, art galleries, cultural events). They could be in the public realm such as a nature park, cultural or historical sites or could be community attractions and services such as culture, heritage or lifestyle. Other, less tangible factors, such as uniqueness and emotional or experiential triggers are also attracting tourists to destinations [6]. According to Indonesian law number 10, 2009, tourist attraction is every resource that has uniqueness, beauty and value in the form of natural, cultural and artificial diversity which is targeted to be the goal of tourists visit [2]. To be a tourist attraction there are some requirements to fulfill :

1. What to see

The tourism object must have different attraction with other area. In other words, it must have special attraction and cultural attraction to be an entertainment for the tourists. It covers the panorama, activities, arts, and tourist attraction.

2. What to do

Besides what to see, tourism object should provide recreation facility to extend the tourist's length of stay.

3. What to buy

The tourist destination should provide the shopping facilities, particularly souvenirs and local handicraft as the gift and souvenir

4. What to arrive

It covers accessibility, how tourist visits the tourist attraction, what means of transportation will be used, and the travel time to reach the tourist destination

5. What to stay 
It is how the tourists will stay for a certain period of time when they have their holiday. It is necessary to provide the accommodation either star hotel or nonstar hotel, etc.

\section{Methodology}

This study employed qualitative approach. The source of data is selected purposively by using several informants who knows about the tourism potential in Nagari Kamang Hilia. The data is collected by using observation, in depth interview and documentation study. Check list observation is used as a tool while observing the area of Nagari Kamang Hilia. Besides, some questions were provided to gain information about tourism potential in Nagari Kamang Hilia. Next, reduction process and data verification, are conducted inductively before the data is displayed. The data is analyzed using triangulation technique by comparing the data obtained from observation, in depth interview and documentation study.

\section{Results and Discussion}

\subsection{An Overview on Nagari Kamang Hilia, Agam Regency}

Nagari Kamang Hilia is located in Padang Magek District, Agam Regency, West Sumatera. It is led by Wali Nagari who is selected by the people in Nagari Kamang Hilia. The location is about $89 \mathrm{~km}$ from the center of government in Lubuk Basung. This area is 850 meters above sea levels, with the temperature about $19-27$ degrees celsius and it has moderate climate. On the north, it borders with Bukit Barisan Lima Puluh Kota Regency, while in the west it borders with Nagari Kamang Mudiak. On the east, it borders with Nagari Salo Baso District and on the south, it borders with Nagari Magek, Kamang Magek District. To reach the Nagari Kamang Hilia, the accessibility is by using land transportation passing Nagari Magek, Kamang Mudiak and Salo.

The origin name of Nagari Kamang can be tracked through Tambo Nagari Kamang which is adopted from the history of Minangkabau Kingdom. Tambo is a history which is mixed with in fairy tales. Some clans of wanderers from Pagaruyung tried to find a new land as the extension of their territory. Then, the leader of the clan, found an area which had high rocks and they lived there. Usually, every afternoon they gathered and discussed some issues related to the communities under a tree, and it will be started with the question "Kamanga awak lai?" which means what are we going to do next? Finally the tree was called with "Kayu Kamang". Later, after a few times the name of the area changed to "Nagari Kamang". In the war defended the Indonesian independence in 1949, some figures in Nagari Kamang held a meeting in Anak Air Dalam Koto Kamang (an area in Nagari Kamang) and agreed to add the word Hilia at the end of name Kamang so the name turned into "Kamang Hilia" and the name of Nagari Surau Koto Samiak changed into "Kamang Mudiak".

The total area of Nagari Kamang Hilia is $16 \mathrm{~km}^{2}$ and only half of the area inhabited by people because the rest of the area are hill and forest. In 2018, population is about 5869 people with 2912 males and 2957 females. It consists of 17 Jorong (villages), the largest is Jorong Dalam Koto with the coverage area about $1500 \mathrm{~m}^{2}$ and the smallest is Jorong Binu with the total area is $70 \mathrm{~m}^{2}$. The largest population is in Jorong Dalam Koto with the total of 712 people and the smallest population is in Jorong Binu with the total of 87 people. as listed in the Table 1 below: 
Tabel 1. The total area and population of Nagari Kamang Hilia.

\begin{tabular}{|c|c|c|c|c|c|}
\hline \multirow{2}{*}{ No } & \multirow{2}{*}{ Jorong (Village) } & \multirow{2}{*}{$\operatorname{Area}\left(\mathbf{M}^{2}\right)$} & \multicolumn{3}{|c|}{ Number of Population } \\
\hline & & & Male & Female & Total \\
\hline 1 & 2 & 3 & 4 & 5 & 6 \\
\hline 1. & Jorong Koto Panjang & 530 & 233 & 257 & 490 \\
\hline 2. & Jorong Dalam Koto & 1500 & 358 & 354 & 712 \\
\hline 3. & Jorong Dangau Baru & 870 & 152 & 160 & 312 \\
\hline 4. & Jorong Batu Baraguang & 750 & 152 & 159 & 311 \\
\hline 5. & Jorong Solok & 110 & 134 & 124 & 258 \\
\hline 6. & Jorong Bancah & 120 & 151 & 139 & 290 \\
\hline 7. & Jorong IV Kampuang & 250 & 256 & 264 & 520 \\
\hline 8. & Jorong V Kampuang & 230 & 185 & 165 & 350 \\
\hline 9. & Jorong Koto Nan Gadang & 570 & 119 & 129 & 248 \\
\hline 10. & Jorong Binu & 70 & 51 & 36 & 87 \\
\hline 11. & Jorong Balai Panjang & 120 & 85 & 87 & 172 \\
\hline 12. & $\begin{array}{l}\text { Jorong Guguak } \\
\text { Rangpisang }\end{array}$ & 150 & 105 & 117 & 222 \\
\hline 13. & Jorong Koto Kaciak & 120 & 93 & 99 & 192 \\
\hline 14. & Jorong Nan VII & 1320 & 251 & 247 & 498 \\
\hline 15. & Jorong Pintu Koto & 1260 & 282 & 305 & 587 \\
\hline 16. & Jorong Ladang Darek & 970 & 189 & 200 & 389 \\
\hline 17. & Jorong Joho & 90 & 116 & 115 & 231 \\
\hline & Total & 9030 & 2912 & 2957 & 5869 \\
\hline
\end{tabular}

Source : Nagari Kamang Hilia, Agam Regency 2019

\subsection{Tourist Attraction}

Based on observation and interview with some informants, out of 17 villages in Nagari Kamang Hilia, there are 9 villages that have tourist attractions namely Jorong Batu Baraguang, Jorong Solok, Jorong Bancah, Jorong Koto Nan Gadang, Jorong Binu, Jorong Guguak Rangpisang, Jorong Pintu Koto and Jorong V Kampuang. The potential tourist attractions are classified into natural attraction, cultural attraction and artificial attraction as listed in the Table 2 below :

Tabel. 2. Tourist Attractions in Nagari Kamang Hilia.

\begin{tabular}{|c|c|c|c|c|}
\hline \multirow{2}{*}{ NO } & \multirow{2}{*}{$\begin{array}{c}\text { Jorong } \\
\text { (Villages) }\end{array}$} & \multicolumn{3}{|c|}{ Attraction } \\
\hline & & Natural & Cultural & Artificial \\
\hline 1 & 2 & 3 & 4 & 5 \\
\hline 1. & $\begin{array}{l}\text { Jorong Batu } \\
\text { Baraguang }\end{array}$ & $\begin{array}{ll}- & \text { Rice fields view } \\
\text { - } & \text { Forest }\end{array}$ & - & - \\
\hline 2. & Jorong Solok & $\begin{array}{ll}- & \text { Karst rocks } \\
- & \text { Hill } \\
- & \text { Forst }\end{array}$ & $\begin{array}{ll}\text { - } & \text { Local Art work } \\
& \text { Community } \\
\text { - } & \text { Martial arts (silat) }\end{array}$ & - \\
\hline 3. & Jorong Bancah & $\begin{array}{ll}- & \text { Karst rocks } \\
- & \text { Forest }\end{array}$ & - & $\begin{array}{l}\text { Traditional } \\
\text { house (Rumah } \\
\text { Gadang) }\end{array}$ \\
\hline
\end{tabular}




\begin{tabular}{|c|c|c|c|c|}
\hline 4. & Jorong Binu & $\begin{array}{ll}- & \text { Cave } \\
- & \text { Karst rocks } \\
- & \text { Forest }\end{array}$ & $\begin{array}{l}\text { Traditional } \\
\text { culinary }\end{array}$ & $\begin{array}{ll}- & \text { Fish Farm } \\
- & \text { Traditional } \\
& \text { house (Rumah } \\
& \text { Gadang) }\end{array}$ \\
\hline 5. & $\begin{array}{l}\text { Jorong Guguak } \\
\text { Rangpisang }\end{array}$ & $\begin{array}{ll}- & \text { Hill } \\
- & \text { Forest }\end{array}$ & $\begin{array}{l}\text { Traditional } \\
\text { culinary }\end{array}$ & $\begin{array}{ll}\text { - } & \text { Fish Farm } \\
\text { - } & \text { Kids playground } \\
\text { - } & \text { Playing a raft }\end{array}$ \\
\hline 6. & $\begin{array}{l}\text { Jorong Dalam } \\
\text { Koto }\end{array}$ & $\begin{array}{ll}- & \text { Hill } \\
- & \text { Forest }\end{array}$ & $\begin{array}{ll}- & \text { Minangkabau } \\
\text { traditional woven } \\
-\quad & \text { Minangkabau } \\
& \text { Batik handmade }\end{array}$ & - \\
\hline 7 & Jorong Joho & - & $\begin{array}{l}\text { Minangkabau } \\
\quad \text { Batik handmade }\end{array}$ & - \\
\hline 8 & $\begin{array}{l}\text { Jorong Pintu } \\
\text { Koto }\end{array}$ & - & - & $\begin{array}{ll}\text { - } & \text { Monument of } \\
& \text { Kamang War }\end{array}$ \\
\hline 9 & $\begin{array}{l}\text { Jorong V } \\
\text { Kampuang }\end{array}$ & - & - & $\begin{array}{ll}\text { - } & \text { Kamang } \\
& \text { Heroes } \\
\text { cemetery }\end{array}$ \\
\hline
\end{tabular}

Source : Nagari Kamang Hilia, Agam Regency 2019.

\section{Natural Potentials}

As seen from table. 2, the main natural attraction in Nagari Kamang Hilia is the view of hills and paddy rice field. The uniqueness of the nature of Nagari Kamang Hilia is the Karst rocks that can be found in Jorong Solok, Jorong Bancah, Jorong Binu and Jorong Guguak Rangpisang. Karst rock may define as comprising terrain with distinctive hydrology and landforms that arise from a combination of high rock solubility and well developed secondary (fracture) porosity. Such areas are characterized by sinking streams, caves, enclosed depressions, fluted rock outcrops, and large springs. In Nagari Kamang Hilia, the karst rocks then, form cave and rock. The cave and the rock can be found in Jorong Binu and Jorong Guguak Rangpisang. Inside the cave there are some stalagtit and stalagmites that have their own uniqueness. There are two hills in Nagari Kamang Hilia, namely Bukik "Binu" and Bukik "Baka". The forests are also other potentials in Nagari Kamang Hilia that could be develop as tourism potential and they could be found in Jorong Batu Baraguang, Jorong Bancah, Jorong Solok, Jorong Binu, Jorong Guguak Rangpisang and Jorong Dalam Koto. Nagari Kamang Hilia

\section{Cultural Potentials}

Nagari Kamang Hilia has several cultural potentials to be developed for tourism activities. It has local arts communities that still actively practicing the traditional arts from Nagari Kamang Hilia, such as dance performance and typical dance combining with traditional theatrical of Minangkabau which is called "Randai". The communities try to preserve the tradition and encourage the young generation in Nagari Kamang Hilia to participate in the artwork communities. Besides, it also has martial art which is commonly called "silek" as cultural performance and self-defense. Nagari Kamang Hilia also has potentials in culinary, since it has various kinds of traditional cuisines such as "kurabu", "kapecong" and "pua". Kurabu is one of typical cuisine which its main ingredients are "pakis" (a kind of vegetable) and egg- plant which is boiled and marinated with spices. "Pua" is a kind of fresh vegetable which is directly eaten. "Kapecong" is a kind rowal fruit that can be fried or mixed with coconut milk. Other cultural potentials in Nagari Kamang Hilia are Kamang traditional woven and handmade Batik which is processed by the local people, especially by the women. The motifs of traditional woven and handmade batik resemble the nature such as durian flower, and birds. 


\section{Artificial Potentials}

The artificial potentials also plays significant role in a tourist destination. Nagari Kamang Hilia has some artificial potential such as traditional house (Rumah Gadang) that could be found in Jorong Bancah and Jorong Binu. The condition of Rumah Gadang in Jorong Binu is not in good condition since there are some damages in some parts of the house. The people in Jorong Binu have initiative to restore Rumah Gadang to be an art performance site. In Jorong Bancah, Rumah Gadang is in good and well- maintained condition. Fish farm is another artificial attraction in Jorong Guguak Rangpisang which is located in a tourism object called "Luak Gadang". There are two big fish ponds in Luak Gadang containing with fish that has been cultivated by the people who managed Luak Gadang. People visiting Luak Gadang can feed the fish with fish pellets sold by the local people. Visitors can also play the raft to the middle of the fish pond, to reach the artificial ship located in the middle of the fish pond. In addition, Luak Gadang also provide kid's playground around its area. In Jorong Pintu Koto, there is a monument of Kamang War which is located in the junction of Jorong Pintu. It symbolized the struggle of Nagari Kamang people defended their land from the Dutch. Some figures of Nagari Kamang died in the war and they were buried in the area which is now known as the heroes cemetery, located in Jorong V Kampuang.

Besides, in Nagari Kamang Hilia, people plant paddy rice, cocoa, cassava and some typical fruit of Nagari Kamang Hilia such as oranges, durian, and dragon fruit. Based on the interview with the informants, natural attraction in Jorong Binu such as hill and cave has been facilitated with the resources from the local community. However, since they are still lack of facilities in the area of natural attraction, the site is not yet open for public. On the other hand, Luak Gadang which is located in Jorong Guguak Rangpisang has been a tourism object since 2018 and opened for public. This tourism object has got supported budget from one of bank's CSR and they used it as the initial capital to provide Luak Gadang with some supported facilities, such as toilet, garbage dumps, kiosk for local people, parking lot etc.

\section{Potential Tourism Development}

Analyzing all the potential Nagari Kamang Hilia has, whether in the form of natural resources, cultural and artificial resources, there are two types of tourism development that possibly suggested to Nagari Kamang Hilia :

1. Rural Tourism

The concept of rural tourism is a tourism activity in an area that offer attraction in the form of all the ambiance that reflect the originality of village, social life, economy, local custom, building architecture or the typical village spatial. Rural tourism can be defined as the country experience" which encompasses a wide range of attractions and activities that take place in agricultural or non-urban areas. Its essential characteristics include wide-open spaces, low levels of tourism development, and opportunities for visitors to directly experience agricultural and/or natural environments[7]. Rural tourism is not just farm-based tourism. It includes farm-based holidays but also comprises special interest nature holidays and ecotourism, walking, climbing and riding holidays, adventure, sport and health tourism, hunting and angling, educational travel, arts and heritage tourism, and, in some areas, ethnic tourism. [8] A major form of tourism is agritourism, which refers to, the act of visiting a working farm or any agricultural, horticultural or agribusiness operation for the purpose of enjoyment, education, or active involvement in the activities of the farm or operation. The diversity of attractions included within rural tourism includes heritage tourism (sometimes referred to as cultural heritage tourism), nature-based tourism/ecotourism, agritourism, as well as partnership-based approaches, such as scenic byways and heritage areas. Heritage tourism refers to leisure travel that has as its primary purpose the experiencing of places and activities that represent the past.[9] 
Nagari Kamang Hilia that consists of 17 Jorong (villages) could develop rural tourism in term of the availability of several potentials. The daily life of the community is the main attraction of tourist visits to Nagari Kamang Hilia. The majority of the people in Nagari Kamang Hilia are farmers, so this condition possibly supports the rural tourism activities in this area. The beautiful view of the rice field in Nagari Kamang Hilia and the peaceful atmosphere will benefit to the healthy mind of the tourists. They can do activities as the local people do, like planting the paddy in the rice field and learn to cook traditional cuisine of the local people. In the fruit season, particularly for durian, the tourist may involve in the activity waiting for durian fall. The local residence houses could be used for the accommodation as homestay. The tourists may have a chance to stay in the homestays that managed by the local community. Based on information from Head of Jorong in Jorong Binu, there are some local residences that have potential to be homestay. In addition, there are two traditional houses of Minangkabau (Rumah Gadang) that still existed in Nagari Kamang Hilia, and they have potential to use as accommodation for the tourists. They could have experience staying in Rumah Gadang, and learn what local people do in their daily life. However, to develop rural tourism, Nagari Kamang Hilia should be facilitated with the infrastructure to support the tourism activity. The accessibility to the villages in Nagari Kamang Hilia has been connected to the main road to Bukittinggi and to the capital of the regency Lubuk Basung. The accessibility to Nagari Kamang Hilia is in circle route and could be passed by two and four wheel vehicle. Due to the narrow street in Nagari Kamang Hilia, the bus could not access the road. So, there should be alternative for the tourists to reach the destination. Local people could create typical means of transportation to access the villages in Nagari Kamang Hilia. They possibly use the traditional transportation such as the cow wagon. It also could be attractive for the tourists to use such traditional transportation.

Nagari Kamang Hilia could also emerge the tourism activities in terms of cultural and heritage. The potential of traditional woven and handmade batik may involve the tourists to see the making process and they could possibly try to engage in such activities. Furthermore, the tourist can buy the product as souvenir when they leave Nagari Kamang Hilia. This area has some traditional dances and typical martial art called "silek harimau". The tourists may learn traditional dances from Kamang Hilia, such as "tari piriang" and "randai" that combine between the music and the movement of the dancer. In addition, in Nagari Kamang Hilia there is a monument of Kamang War which is located in Jorong Pintu Koto, to commemorate the figures who have defended Nagari Kamang Hilia from the Dutch colonial in the past. There were several people that died in the war and they were buried in the Kamang Heroes Cemetary which is located in Jorong V Kampuang. All of the heritage could possibly manage into cultural and heritage tour activities.

By developing rural tourism in Nagari Kamang Hilia, the local community could run small enterprises related to the needs of the tourists to support the tourism activities in Nagari Kamang Hilia. The local government of Kanagarian Kamang Hilia should manage the empowerment of local community to enhance the capacity of human resources of the local community which in turn that will manage the the tourism activities in Nagari Kamang Hilia.

2. Adventure Tourism

Nagari Kamang Hilia has natural potencies to develop adventure tourism. Adventure tourism can be defined as travel and leisure activities that are bought into in the hope that they will produce a rewarding adventure experience", provoke a range of emotions such as excitement. Adventure tourism can be divided into two sectors namely 'hard' and 'soft' adventures. Hard adventure require that the tourists have some experience and skills in the activity before undertaking the tourism experience, in contrast to soft adventures that not necessarily require previous experience exotic 
locations [10]. The activities undertaken during the trip are low risk and low intensity activities. Soft adventure travel is a more luxury form of travelling. These types of tourists like to enjoy high quality food, stay in quality lodging and use quality transportation [10]. Activities such as birdwatching, fishing, hiking, horseback riding, sailing and scuba diving are examples of soft adventure activities [11]. Nagari Kamang Hilia could possibly manage the adventure activities such as caving, and soft trekking to the hill. Since it has the natural potentials of cave and hills, Nagari Kamang Hilia could develop such activities to involve the tourist in exploring the beauty of the caves and learning something new from the trip The tourists, especially nature lovers could have the adventure experience of Nagari Kamang Hilia. They also could enjoy the local food during their adventure trip in Nagari Kamang Hilia. However, to accompany the tourists, Nagari Kamang Hilia should facilitate the human resources who are competence in caving and trekking activities. They must be provided with certain training due to their competencies in guiding the adventure tourists.

\section{Conclusion}

Tourism potentials play an important role in the development of a tourist destination. The tourist attraction is the key to attract the tourists visit to a destination. This study explores the tourism potentials in Nagari Kamang Hilia using the concept of tourist attraction. It can be concluded that Nagari Kamang Hilia has tourism potentials to be developed, since nine villages (jorong) have tourist attraction in the form of natural attraction, cultural attraction and artificial attraction. It has fulfill the requirements to be a tourist attraction by identifying what to see, what to do, what to buy, what to arrive and what to stay.

Nagari Kamang Hilia could possibly develop two types of tourism development, namely rural tourism and adventure tourism viewed from potentials prospective. The combination of natural attraction in the form of rural scenic view of Nagari Kamang Hilia, the way of living of the local people, the culture and heritage, and agriculture, rural tourism is the best type of tourism development to emerge. In addition to the natural beauty of Nagari Kamang Hilia in the form of caves and hills, adventure tourism is the right choice to develop. All of the resources are very potential to develop as a tourism destination by focusing on the strength of the potential it has. Nagari Kamang Hilia should possibly manage and create packaging towards all the potentials to attract the tourists visit. Hence it will enhance the economy of the local people by empowering all levels of the community in Nagari Kamang Hilia.

\section{References}

[1] T. Rifai, “Annual Report World Tourism Organization 2016,” 2017.

[2] Kemenkumham, Undang-Undang R.I. No. 10 Tahun 2009 Tentang Kepariwisataan. 2009.

[3] M. Sánchez Rivero, J. M. Sánchez Martín, and J. I. Rengifo Gallego, "Methodological approach for assessing the potential of a rural tourism destination: An application in the province of Cáceres (Spain)," Curr. Issues Tour., 2016.

[4] UNWTO, "UNWTO Tourism Highlights," 2016.

[5] P. J. Benckendorff, "PLANNING FOR THE FUTURE A Study of Australian Tourist Attractions," Summ. Rep. Aust. Tour. Attract., 2001.

[6] D. Ford and P. Williams, Karst Hydrogeology and Geomorphology. John Wiley and Sons Ltd., 2013.

[7] R. D. Division, "Rural Tourism - an Overview October 2010," J. Sustain. Tour., no. October, 2010.

[8] R. D. Division, "RURAL TOURISM - AN OVERVIEW OCTOBER 2010,” J. Sustain. Tour., no. October, 2010

[9] G. Wall and V. L. E. Smith, "Tourism alternatives in an era of global climatic change.," Tour. 
Altern. potentials Probl. Dev. Tour., 1992.

[10] P. Beedie, "Adventure tourism," Routledge Int. Handb. Outdoor Stud., no. July, pp. 463-471, 2016.

[11] Organización Mundial de Turismo, "Global Report on Adventure Tourism," Anim. Genet., 2014. 